$\therefore$ ヒே ル

10XV

\title{
無機系導電性 材 料
}

高分子材料は本質的には絶緑性であるが，電気遵電性を付与することによって，エレクトロニクス関連を中心に その用途は著しく拡大している。2 月号で紹介した導電性高分子（ポリピロール，ポリアセチレンなど）の研究開 発は急ピッチで進められているが，現在実用化されている導電性プラスチックのほとんぞは，導電性材料と既存プ ラスチックとの複合物である。

そこで使用されている導電性材料は金属の粉末・織維・フレーク，グラファイト粉末，カーボンブラック，炭素 㵶維，酸化錫や ITO (インジゥム・錫オキサイド) などの無機粉体であるが，最近無機系でも繊維状やフレーク 状の導電性材料が開発され注目をあびている。これは点（粉状）よりも効率の良い線（㵶維状），面（フレーク状） への移行とみることができる。

導電性複合高分子材料の製法として

（1）ブラスチック基体表面に導電性被膜を形成する方法

真空蒸着，スパッタリンク，イオンブレーティング，化学メッキ，導電性材料を含む塗料を塗装する方法な

ど導電性被膜を形成させるもので，透明導電性フィルムや電磁波シールド等に実用化されている。

(2) 導龟性材料をプラスチック中に分散充填する方法

（3）尊電性材料（マット，金銅など）とブラスチック材料とを積層する方法 などがある。 尊電性材料としては銀が最も導電性が良い（体積抵抗率 $1.6 \times 10^{-6} \Omega \cdot \mathrm{cm}$ ) が高価なため銅 $\left(1.7 \times 10^{-6}\right)$ ，フルミ ウム $\left(2.7 \times 10^{-6}\right)$, ニッケル $\left(7.0 \times 10^{-6}\right)$ などの粉末が使われる。しかし, これらは充填量を増すとプラスチック の機械的物性や成形加工性を低下させる問題がある。金属瀻維も使われるが，これも物性や加工性流影響する。力 一ボンブラックやグラフフイト粉末もよく使われるが黒くなる欠点がある。東邦レーヨンが表面を金属膜で被覆し た炭素䄉維を開発し，導電性の高強度瀻維として電磁波シールド材への利用が期待されているがかなり高価である。

無機化合物では ITO がプラスチックフィルムやガラス基板上に導電性被膜を作る目的で広く利用されている。 酸化錫系の導電性粉末としては三菱金属，触媒化成などから酸化錫に酸化アンチモンをドープしたものとか，酸化 チタンの表面を酸化アンチモンドープ酸化錫で被覆したものが市眅され，基材表面に透明導電膜を叙布により形成 する目的で使われるが値段はかなり高価である。

ブラスチックに分散・充填する導電材料としては，それが接触して導電性が付与されるので粉体よりるアスペク ト比の大きい材料の方が効率的である。天然の鳞状グラフィイトを $0.1 \sim 10 \mu$ 程度に粉碎したもののアスペクト比 は10〜数 10 程度にすぎないか，大工試が新しく開発した技術では最大 700 程度まで可能であるという。しかし複 合材料の黑色化は避けられない。これに対し大塚化学の導電性ウイスカー（商品名デントール），帝国化工の導軍 性マイカ（MEC シリーズ）は白色あるいは透明性の導電材料である。

デントールは六チタン酸カリウムウイスカーに導電性を付与したすのといわれており，BK シリーズ（青灰色〜 黒灰色）とWK シリーズがある。 $\mathrm{BK}$ シリーズは $\mathrm{K}_{2} \mathrm{O} \cdot \mathrm{nTiO}_{2} \mathrm{x}$ で表わされ還元焼成する際洒素が抜けて導電 性をもつよ5になるとい5。WK シリーズは表面処理されたもので白色系である。瀻維状であるため粉末よりも 少ない添加量で導電性が得られるウイスカーであるため補強奻果があり, また耐摩耗性, 表面平滑性, 加工性（二 ソパウンド流動性), 寸法安定性にすぐれた成形品が得られるとい5。

MEK は透明なマイカフレークの表面を超微粒子酸化錫と酸化アンチモンでューテングした遒電性材料である。 樹脂に混合したり表面塗布用として使用されている。扁平状なので粒子間の重なりによる接触が良く(リーフィン グ効果）粉末状のものに比へてて少い量ですぐれた導䉓性被膜が得られる。透明・淡色の導電膜なのでカラーリング 邩刷が可能である。樹脂に混合した場合には補強効果もある。IC，太陽䉓池用透明電極，静電気除去，带電防 止, 電着塗装静電記録材料などへの用途が見込まれている。

マイカ粉末を使った導電材料としては，このほか三菱金属のニッケルコーティングしたマイカがあり，これは電 磁波シールド材の塗布剤として使用されている。

体穎抵抗率 $(\Omega \cdot \mathrm{cm})$
$>10^{10}$
$>10^{6}$
$10^{1} \sim 10^{6}$
$10^{3}$
$<10^{3}$

道奄性（体程抵抗柬）之用途の関係

機 能・用 途

帯電防止 ( I C ・電子部品・精密機器等の棝包・ガソリンタンク)

静電気除去（ロール，ベルト，床材，内装材等）

面発熱体，抵抗体

電極

電磁波シールド 